\title{
Optimization of Cellulase Enzyme Production by Co-cultures of Fungi Isolated from Lignocellulosic Waste
}

\author{
Francis John $\mathrm{V}^{1} \mid$ Dr. Soloman $\mathrm{P}^{2}$
}

\begin{abstract}
${ }^{1}$ Department of Biotechnology Engineering, Sahrdaya College of Engineering and Technology, Thrissur, Kerala,India 2Department of Chemical Engineering, Government Engineering college, Thrissur, Kerala,India
\end{abstract}

\section{To Cite this Article}

Francis John V and Dr. Soloman P A, “Optimization of Cellulase Enzyme Production by Co-cultures of Fungi Isolated from Lignocellulosic Waste", International Journal for Modern Trends in Science and Technology, Vol. 06, Issue 05, May 2020, pp.:19-26; https://doi.org/10.46501/IJMTST060504

Article Info

Received on 24-March-2020, Revised on 20-April-2020, Accepted on 25-April-2020, Published on 29-April-2020.

\section{ABSTRACT}

Fruit wastes were incubated with the mixture of cellulolytic fungi Penicillium citrinum, Aspergillus oryzae, and Trichoderma viride to hydrolyze the cellulosic components and to increase the degree of degradation. The batch experiments are statistically designed and performed using Box-Benhken method of Response Surface Methodology to investigate the influence of major parameters viz., incubation time, temperature, $p H$, moisture content and substrate concentration on cellulase enzyme production. Maximum cellulase production of 2.03 Units $/ \mathrm{ml}(\mathrm{U} / \mathrm{ml})$ was detected by the RSM method in a mixed culture containing fungi at a ratio of 1: 1: 1 under optimal conditions at an incubation time of 5.27 days, a temperature of $34.09{ }^{\circ} \mathrm{C}, \mathrm{pH} 4.85$, moisture content of $63.83 \%$ and a substrate concentration of $5.03 \%$.

KEYWORDS: Fruit waste, Mixed culture, Optimization, Cellulase production

Copyright (c) 2014-2020 International Journal for Modern Trends in Science and Technology . All rights reserved. DOI: https://doi.org/10.46501/IJMTST0605004

\section{INTRODUCTION}

The worldwide supply of non-renewable form of energy is entering a phase of decline, while the requirement for energy is mounting. The current universal demand for energy is mainly met by utilizing fossil fuel resources such as coal, oil and petroleum. With the global increasing demand for energy, energy shortage will be a worldwide problem. There is also widespread prediction that the world population will likely increase by $50 \%$ in the next 50 years with increase in the world demand for petroleum energy (Igbinadalor,2012). The significance of alternate source of bioenergy has gained a lot of importance not only because of the continuous exhaustion of limited reserves of fossil fuels, but also for safer use of the surroundings and, as a result, a source of sustainable energy.

Lignocellulosic waste is produced daily all over the world in huge quantities through agricultural practices, mainly from different agricultural and forestry industries. These renewable materials accumulate a lot in the world and, if not exploited properly, they will cause environmental pollution. But if used correctly, it will benefit the economic development of our country.

"The hassle in waste utilization is to develop a process that is economically feasible and safe.. Bioconversion offers an inexpensive and safe method of disposing these wastes. It also has the 
potential to convert the waste into usable forms such as substrate for production of cellulase enzymes and reducing sugars that can be used for fuel production".(Acharya et al., 2008).

Microorganisms are important in the bioconversion of cellulosic waste and in the production of enzymes from waste. Although bacteria and fungi can produce cellulases, fungal cellulases are generally preferred because they are extracellular, adaptive and generally secreted in large quantities (up to $2 \%$ by weight) during growth. "According to Maciel et al., 2008 cellulase enzymes are mainly produced from Trichoderma species, Aspergillus species and Penicillium species."

In this work, we focus at the relative potentials of fruit waste as microbial substrate for cellulase enzyme production by utilizing strains of A. oryzae, P.citrinum and T. viride as a mixed culture. These strains are isolated from lignocellulosic wastes. Also in a mixed culture a synergistic effect is present where the fungi co-operate and the effect on cellulase enzyme production is greater than the sum of the effects in the individual monocultures.

\section{Materials \& Methods}

\section{A. Cellulosic Materials}

The rotten fruit waste which was used as substrate was collected in a sterile container and agitated on a rotary shaker at $250 \mathrm{rpm}$ for 1 hour to disperse the sample. These samples were diluted and spread plated on a starch case in medium. The plates were incubated for 7 days at $28^{\circ} \mathrm{C}$.

\section{B. Microbial Stains}

Fungi P.citrinum, A.oryzae and T.viride were isolated from decayed lignocellulosic Waste. The culture was maintained on potato dextrose agar slant at $4^{\circ} \mathrm{C} \&$ sub-cultured on fresh sterile PDA slant $\&$ incubated for $72-120 \mathrm{hr}$.

\section{Cellulase Assay}

"Cellulase activity was measured as per the 3, 5dinitrosalicylic acid (DNS) methods (Mandels, 1969) by determining the amount of reducing sugars released during 30 minutes in a reaction mixture. The cellulase activity was assayed by mixing $0.5 \mathrm{ml}$ of culture supernatant with $0.5 \mathrm{ml}$ of $1 \%$ carboxy methyl cellulose solution in $0.5 \mathrm{M}$ acetate buffer $\mathrm{pH}$ 5 for fungal enzymes and incubated for 30 minutes at $50 \circ$ c. One unit (U) of enzyme activity was defined as the amount of enzyme releasing $1 \mu$ mole reducing sugar in 1 minute reaction".

\section{Cellulase enzyme production using fruitwaste as substrate}

" 10 grams of fruit waste was moistened with Mandel and Reese medium to get initial moisture content of $50 \%$ and autoclaved at $1210 \mathrm{C}$ for 15 minutes at 15 psi pressure. After cooling, sterilized flask were inoculated with mixed cultures. For mixed cultures (mixture of three fungi), $1 \mathrm{ml}$ of each culture was added. The final spore concentration was maintained as $3 \times 106$ spores $/ \mathrm{ml}$. The content in the flask were mixed thoroughly to ensure uniform distribution of inoculums and flask was incubated at $300 \mathrm{C}$ for 12 days. The samples were withdrawn after each day till 10thday and estimated cellullase activity (Rahana et.al 2014)

\section{E. Optimization of enzyme production}

In order to find the influences of Incubation time, temperature, $\mathrm{pH}$, substrate concentration and moisture content for optimization of cellulase enzyme production, mixed fungal strains were cultivated with incubation time of 1-10 days, varying temperatures of $15^{\circ} \mathrm{C}-45^{\circ} \mathrm{C}, \mathrm{pH}$ range $2-8$, moisture content of $40 \%-80 \%$ and substrate concentration of $2 \%-7 \%$ by keeping all other parameters constant for 10 days.

\section{F. Experimental design}

Our work is based on determining the relationship between the amount of cellulase enzyme production and operating parameters such as Incubation time, temperature, $\mathrm{pH}$, moisture content and substrate concentration, "Response surface methodology (RSM) is used as a statistical technique for the modeling and optimization of various variables, which determines the optimum process conditions" (Fang H 2010). Table 1 gives the parameters and the operating ranges covered.

Table 1 The level and range of variables chosen for cellulase enzyme production.

\begin{tabular}{|l|l|l|l|}
\hline Independent variable & \multicolumn{3}{|l|}{ Coded levels } \\
\hline Incubation time(days) & $\mathbf{- 1}$ & $\mathbf{0}$ & $\mathbf{1}$ \\
\hline Temperature $\left({ }^{\circ} \mathrm{C}\right)$ & 1 & 5.5 & 10 \\
\hline Initial pH & 15 & 30 & 45 \\
\hline Moisture content $(\%)$ & 2 & 5 & 8 \\
\hline Substrate Concentration & 40 & 60 & 80 \\
\hline
\end{tabular}


"The Substrate concentration, $\mathrm{pH}$, and temperature are referred by uncoded variables as X1, X2 and X3 respectively. The variables in uncoded form are converted to coded form: $\mathrm{x} 1, \mathrm{x} 2$ and $\mathrm{x} 3$ using the following equation." (P.A Solomon 2009)

$$
x=\frac{X-\left(\left(X_{\max }+X_{\min }\right) / 2\right)}{\left(\left(X_{\max }-X_{\min }\right) / 2\right)}
$$

"The Box-Behnken experimental design of RSM has been chosen to find the relationship between the response functions and variables using the statistical software tool MINITAB 16 (PA, USA). In the Box-Behnken method a total number of 46 experiments are carried out to estimate the amount of cellulose enzyme production. The interaction between the variables and the analysis of variance
(ANOVA) has been studied by using RSM. The quality of the fit of this model is expressed by the coefficient of determination R2 (A.M Manilal and P.A Solomon 2020)

\section{RESULTS AND DISCUSSIONS}

\section{A. Response surface methodology}

The responses viz. cellulase enzyme production for different combinations of Incubation time, temperature, initial $\mathrm{pH}$,

moisture content and substrate concentration for the 46 sets of experimental conditions as proposed by the RSM design are reported in Table 2 . In order to make sure the consistency of results, every run was carried out thrice, average being reported.

Table 2 Design of experiment and experimental response for cellulase enzyme production

\begin{tabular}{|c|c|c|c|c|c|c|}
\hline 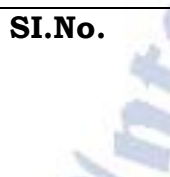 & $\begin{array}{l}\text { Time (Days) } \\
\text { X1 }\end{array}$ & $\begin{array}{l}\text { Temperature }\left({ }^{\circ} \mathrm{C}\right) \\
\mathrm{X} 2\end{array}$ & $\begin{array}{l}\text { pH } \\
\text { X3 }\end{array}$ & $\begin{array}{l}\text { Moisture } \\
\text { content } \\
\mathrm{X} 4\end{array}$ & $\begin{array}{l}\text { Substrate } \\
\text { Concentration } \\
\text { X5 }\end{array}$ & $\begin{array}{l}\text { Cellulase } \\
\text { enzyme } \\
\text { production } \\
(\mathrm{U} / \mathrm{ml})\end{array}$ \\
\hline 1 & 1.0 & 15 & 5 & 60 & 7.0 & 1.4483 \\
\hline 2 & 10.0 & 15 & 5 & 60 & 4.5 & 1.6338 \\
\hline 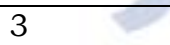 & 1.0 & 30 & 8 & 60 & 7.0 & 1.6460 \\
\hline 4 & 5.5 & 30 & 5 & 60 & 4.5 & 1.9900 \\
\hline $5 \%$ & 5.5 & 30 & 2 & 40 & 4.5 & 1.6830 \\
\hline 6 & 10 & 30 & 5 & +2 & 7 & 1.5603 \\
\hline 7 & 5.5 & 45 & 2 & 80 & 4.5 & 1.7310 \\
\hline 8 & 5.5 & 15 & 8 & 80 & 4.5 & 1.5778 \\
\hline 9 & 5.5 & 15 & 5 & 60 & 2.0 & 1.4750 \\
\hline 10 & 5.5 & 45 & 5 & 60 & 2.0 & 1.6247 \\
\hline 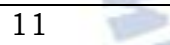 & 5.5 & 15 & 5 & 60 & 7.0 & 1.6135 \\
\hline 12 & 5.5 & 30 & 5 & 60 & 4.5 & 1.9960 \\
\hline 13 & 1.0 & 45 & 2 & 60 & 4.5 & 1.5210 \\
\hline 14 & 10.0 & 30 & 2 & 60 & 4.5 & 1.6828 \\
\hline 15 & 1.0 & 45 & 8 & 60 & 4.5 & 1.4315 \\
\hline 16 & 10.0 & 30 & 5 & 60 & 4.5 & 1.8280 \\
\hline 17 & 5.5 & 45 & 2 & 40 & 2.0 & 1.3545 \\
\hline 18 & 10.0 & 45 & 5 & 80 & 2.0 & 1.3433 \\
\hline 19 & 5.5 & 30 & 5 & 40 & 7.0 & 1.7507 \\
\hline 20 & 5.5 & 30 & 5 & 80 & 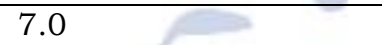 & 1.7530 \\
\hline 21 & 5.5 & $>$ & 2 & 60 & 4.5 & 1.4800 \\
\hline 22 & 5.5 & 30 & 5 & 60 & 4.5 & 1.9990 \\
\hline 23 & 5.5 & 15 & 8 & 60 & 4.5 & 1.6200 \\
\hline 24 & 5.5 & 30 & 5 & 60 & 4.5 & 2.0210 \\
\hline 25 & 1.0 & 45 & 5 & 40 & 7.0 & 1.4540 \\
\hline 26 & 10.0 & 45 & 5 & 40 & 4.5 & 1.7017 \\
\hline 27 & 1.0 & 45 & 5 & 80 & 7.0 & 1.7890 \\
\hline 28 & 10.0 & 30 & 5 & 80 & 4.5 & 1.6575 \\
\hline 29 & 1.0 & 45 & 2 & 60 & 2.0 & 1.2005 \\
\hline 30 & 5.5 & 30 & 8 & 60 & 2.0 & 1.4525 \\
\hline 31 & 5.5 & 30 & 2 & 60 & 7.0 & 1.6506 \\
\hline 32 & 5.5 & 30 & 8 & 60 & 7.0 & 1.6700 \\
\hline 33 & 1.0 & 45 & 5 & 60 & 2.0 & 1.2873 \\
\hline
\end{tabular}


Francis John V and Dr. Soloman P A, "Optimization of Cellulase Enzyme Production by Co-cultures of Fungi Isolated from Lignocellulosic Waste"

\begin{tabular}{|l|l|l|l|l|l|l|}
\hline 34 & 10.0 & 45 & 5 & 60 & 2.0 & 1.4707 \\
\hline 35 & 1.0 & 45 & 8 & 60 & 7.0 & 1.4840 \\
\hline 36 & 10.0 & 30 & 5 & 60 & 4.5 & 1.8669 \\
\hline 37 & 5.5 & 15 & 5 & 40 & 4.5 & 1.6478 \\
\hline 38 & 5.5 & 30 & 5 & 40 & 4.5 & 1.8700 \\
\hline 39 & 5.5 & 15 & 5 & 80 & 4.5 & 1.6525 \\
\hline 40 & 5.5 & 30 & 5 & 60 & 4.5 & 1.9980 \\
\hline 41 & 5.5 & 30 & 5 & 60 & 4.5 & 2.0377 \\
\hline 42 & 5.5 & 30 & 5 & 60 & 4.5 & 2.0195 \\
\hline 43 & 5.5 & 30 & 5 & 60 & 4.5 & 2.0020 \\
\hline 44 & 5.5 & 30 & 5 & 60 & 4.5 & 2.0559 \\
\hline 45 & 5.5 & 30 & 5 & 60 & 4.5 & 1.9649 \\
\hline 46 & 5.5 & 30 & 5 & 60 & 4.5 & 2.0013 \\
\hline
\end{tabular}

"The experimental data obtained were fitted with a total quadratic model with regression coefficients. Other than the intercept, linear, and quadratic terms, the model also reveals the two-way interactions through the interaction terms incorporated. The model can be represented as:

$y=\beta_{0}+\beta_{1} x_{1}+\beta_{2} x_{2}+\beta_{3} x_{3}+\beta_{4} x_{4}+\beta_{5} x_{5}+\beta_{11} x_{1}^{2}+\beta_{22} x_{2}^{2}+\beta_{33} x_{3}^{2}+\beta_{44} x_{4}^{2}+\beta_{55} x_{5}^{2}$

$+\beta_{12} x_{1} x_{2}+\beta_{13} x_{1} x_{3}+\beta_{14} x_{1} x_{4}+\beta_{15} x_{1} x_{5}+\beta_{23} x_{2} x_{3}+\beta_{24} x_{2} x_{4}+\beta_{25} x_{2} x_{5}$

$+\beta_{34} x_{3} x_{4}+\beta_{35} x_{3} x_{5}+\beta_{45} x_{4} x_{5}$

where $\mathrm{y}$ is the amount of cellulase enzyme production in $\mathrm{U} / \mathrm{ml}$. $\beta_{0}$ is a constant, $\beta_{1}, \beta_{2}$ and $\beta_{3}$ are the regression coefficients for linear effects, $\beta_{11}, \beta_{22}$ and $\beta_{33}$ are the quadratic coefficients and $\beta_{12}, \beta_{13}, \beta_{14}, \beta_{23}, \beta_{24}$, and $\beta_{34}$ are the interaction coefficients".(A.M. Manilal and P.A. Solomon 2020). The coefficients of the model are given in Table 3.

Table 3 Estimated regression coefficients and corresponding $t$ - and p-value for cellulase production

\begin{tabular}{|l|l|l|l|l|}
\hline Factor & $\begin{array}{c}\text { Coefficient of the } \\
\text { model in coded factors }\end{array}$ & \multicolumn{1}{|c|}{ t-value } & \multicolumn{1}{c|}{ p-value } & \multicolumn{1}{c|}{$\begin{array}{c}\text { Significance level } \\
\text { (\%) }\end{array}$} \\
\hline$\beta_{0}$ & 2.01 & 276.31 & 0 & significant \\
\hline$\beta_{1}$ & 0.03 & 3.15 & 0.004 & significant \\
\hline$\beta_{2}$ & 0.08 & 8.99 & 0 & significant \\
\hline$\beta_{3}$ & -0.02 & -2.09 & 0.047 & significant \\
\hline$\beta_{4}$ & 0.04 & 4.80 & 0 & significant \\
\hline$\beta_{5}$ & 0.08 & 8.45 & 0 & significant \\
\hline$\beta_{11}$ & -0.19 & -17.46 & 0 & significant \\
\hline$\beta_{22}$ & -0.17 & -13.79 & 0 & significant \\
\hline$\beta_{33}$ & -0.22 & -23.58 & 0 & significant \\
\hline$\beta_{44}$ & -0.11 & -10.62 & 0 & significant \\
\hline$\beta_{55}$ & -0.21 & -21.46 & 0 & significant \\
\hline$\beta_{12}$ & -0.03 & -2.07 & 0.16 & Not significant \\
\hline$\beta_{13}$ & -0.06 & -3.86 & 0.001 & significant \\
\hline$\beta_{14}$ & -0.14 & -7.80 & 0 & significant \\
\hline$\beta_{15}$ & -0.10 & -5.61 & 0 & significant \\
\hline$\beta_{23}$ & -0.10 & -7.98 & 0 & significant \\
\hline$\beta_{24}$ & 0.03 & 2.53 & 0.018 & significant \\
\hline$\beta_{25}$ & 0.026 & 1.98 & 0.15 & Not significant \\
\hline$\beta_{34}$ & 0.04 & 2.98 & 0.006 & significant \\
\hline$\beta_{35}$ & 0.04 & 3.48 & 0.002 & significant \\
\hline$B_{45}$ & -0.039 & -2.54 & 0.018 & significant \\
\hline & & & & \\
\hline
\end{tabular}


By means of above-mentioned cellulase production model proposed by RSM, any combination of these five parameters can be considered within the experimental influence range to predict its quantity. The $\mathrm{p}$-test and t-test were used to analyze the significance of the regression coefficient of cellulase production. Tables 3 and 4 give the "p", "t" and effective levels, respectively. As can be seen from the table, all but two interaction terms have a significant effect on the response. The temperature-substrate concentration interaction term is the least affected term in the model.

The equation can also be written in uncoded form as

$$
\begin{aligned}
& y .=-2.59+0.287 x_{1}+0.055 x_{2}+0.26 x_{3}+0.041 x_{4}+0.384 x_{5}+-0.009 x_{1}^{2}+-.00007 x_{2}^{2}+-0.025 x_{3}^{2}+-0.0003 x_{4}^{2}+-0.033 x_{5}^{2} \\
& +-0.0005 x_{1} x_{2}+-0.005 x_{1} x_{3}+-0.002 x_{1} x_{4}+-0.009 x_{1} x_{5}+-0.002 x_{2} x_{3}+-0.00009 x_{2} x_{4}+0.0006 x_{2} x_{5} \\
& +0.007 x_{3} x_{4}+0.005 x_{3} x_{5}+-0.0008 x_{4} x_{5}
\end{aligned}
$$

\begin{tabular}{|c|c|c|c|c|c|c|}
\hline Source & $\mathbf{d F}$ & $\begin{array}{l}\text { Sum of } \\
\text { squares }\end{array}$ & Mean squares & F-value & p-value & Remark \\
\hline Regression & 20 & 2.340 & 0.1170 & 179.96 & 0 & Significant \\
\hline Linear & 5 & 0.4404 & 0.0214 & 32.94 & 0 & Significant \\
\hline $\mathrm{X}_{1}$ - Incubation Time & 1 & 0.1516 & 0.0064 & 9.72 & 0.005 & Significant \\
\hline $\mathrm{X}_{2}$ - Temperature & 1 & 0.063 & 0.5200 & 78.05 & 0 & Significant \\
\hline $\mathrm{X}_{3}-\mathrm{pH}$ & 1 & 0.00126 & 0.0027 & 4.42 & 0.046 & Significant \\
\hline $\mathrm{X}_{4}$-Moisture concentration & 1 & 0.00007 & 0.0149 & 24.87 & 0 & Significant \\
\hline $\mathrm{X}_{5}$-Substrate Concentration & 1 & 0.2257 & 0.0461 & 69.92 & 0 & Significant \\
\hline Square & 5 & 1.735 & 0.282 & 433.5 & 0 & Significant \\
\hline $\mathrm{X}_{1}{ }^{2}$ & 1 & 0.513 & 0.194 & 296.92 & 0 & Significant \\
\hline $\mathrm{X}_{2}^{2}$ & 1 & 0.4420 & 0.122 & 189.41 & 0 & Significant \\
\hline $\mathrm{X}_{3}^{2}$ & 1 & 0.318 & 0.357 & 550.56 & 0 & Significant \\
\hline $\mathrm{X}_{4}^{2}$ & 1 & 0.064 & 0.072 & 107.23 & 0 & Significant \\
\hline $\mathrm{X}_{5}{ }^{2}$ & 1 & 0.399 & 0.296 & 456.95 & 0 & Significant \\
\hline Interaction & 10 & 0.1618 & 0.0164 & 24.90 & 0 & Significant \\
\hline $\mathrm{X}_{1} \mathrm{X}_{2}$ & 1 & 0.0014 & 0.0026 & 4.16 & 0.14 & Not significant \\
\hline $\mathrm{X}_{1} \mathrm{X}_{3}$ & 1 & 0.0029 & 0.0094 & 14.44 & 0.001 & Significant \\
\hline $\mathrm{X}_{1} \mathrm{X}_{4}$ & 1 & 0.0467 & 0.038 & 57.96 & 0 & Significant \\
\hline $\mathrm{X}_{1} \mathrm{X}_{5}$ & 1 & 0.046 & 0.0198 & 30.53 & 0 & Significant \\
\hline $\mathrm{X}_{2} \mathrm{X}_{3}$ & 1 & 0.046 & 0.0407 & 61.21 & 0 & Significant \\
\hline $\mathrm{X}_{2} \mathrm{X}_{4}$ & 1 & 0.0006 & 0.0041 & 5.51 & 0.018 & Significant \\
\hline $\mathrm{X}_{2} \mathrm{X}_{5}$ & 1 & 0.0017 & 0.0025 & 3.89 & 0.06 & Not significant \\
\hline $\mathrm{X}_{3} \mathrm{X}_{4}$ & 1 & 0.0066 & 0.0057 & 8.27 & 0.007 & Significant \\
\hline $\mathrm{X}_{3} \mathrm{X}_{5}$ & 1 & 0.006 & 0.0077 & 12.28 & 0.002 & Significant \\
\hline $\mathrm{X}_{4} \mathrm{X}_{5}$ & 1 & 0.0039 & 0.0039 & 6.00 & 0.022 & Significant \\
\hline Residual Error & 25 & 0.0163 & 0.0006 & & & \\
\hline Lack-of-Fit & 14 & 0.00943 & 0.0009 & 1.09 & 0.453 & \\
\hline Pure Error & 11 & 0.0068 & 0.0007 & & & \\
\hline Total & 45 & 2.356 & & & & \\
\hline
\end{tabular}

Table 4 ANOVA report for the RSM model of Cellulase enzyme production 

Lignocellulosic Waste"

"Finally, the graphical analyses of the data was done using Analysis of Variance (ANOVA) through the statistical analysis software (MINITAB 16 (PA, USA)). The model terms were evaluated by the p-value (probability) with a 95\% confidence level and the statistical significance was checked by the Fisher F-test. The quality of the fit was expressed by the coefficient of determination $\mathrm{R}^{2}$ and adjusted $\mathrm{R}^{2}$. (A.M Manilal and P.A Solomon 2020)

The importance of the regression coefficients of the parameters on cellulase enzyme production was tested with the Fisher F-test. The regression coefficient values, $F$ value, and $p$-value are obtained in Tables 2 and 3. It can be seen that incubation time, temperature, $\mathrm{pH}$, moisture content and substrate concentration all are most important variables for the cellulase enzyme production which can be linked with the significance of $p$-values which is less than 0.05 .

"Further, the model competency was checked by computing the coefficient of determination $\mathrm{R}^{2}$. The $\mathrm{R}^{2}$ value can reveal how well the model in reproducing the observed outcomes of the experiments. A high $\mathrm{R}^{2}$ value for the coefficient guaranteed satisfactory representation of the proposed model to the experimental observations" (A.M Manilal and P.A Solomon 2020)

\section{B. Combined Effect of Parameters}

The influence of five parameters on quantity of cellulase enzyme production is carried out. Figure 1 shows the contour plots the joint effect of these variables on cellulase production.

\section{Contour Plots of CP (U/ml)}
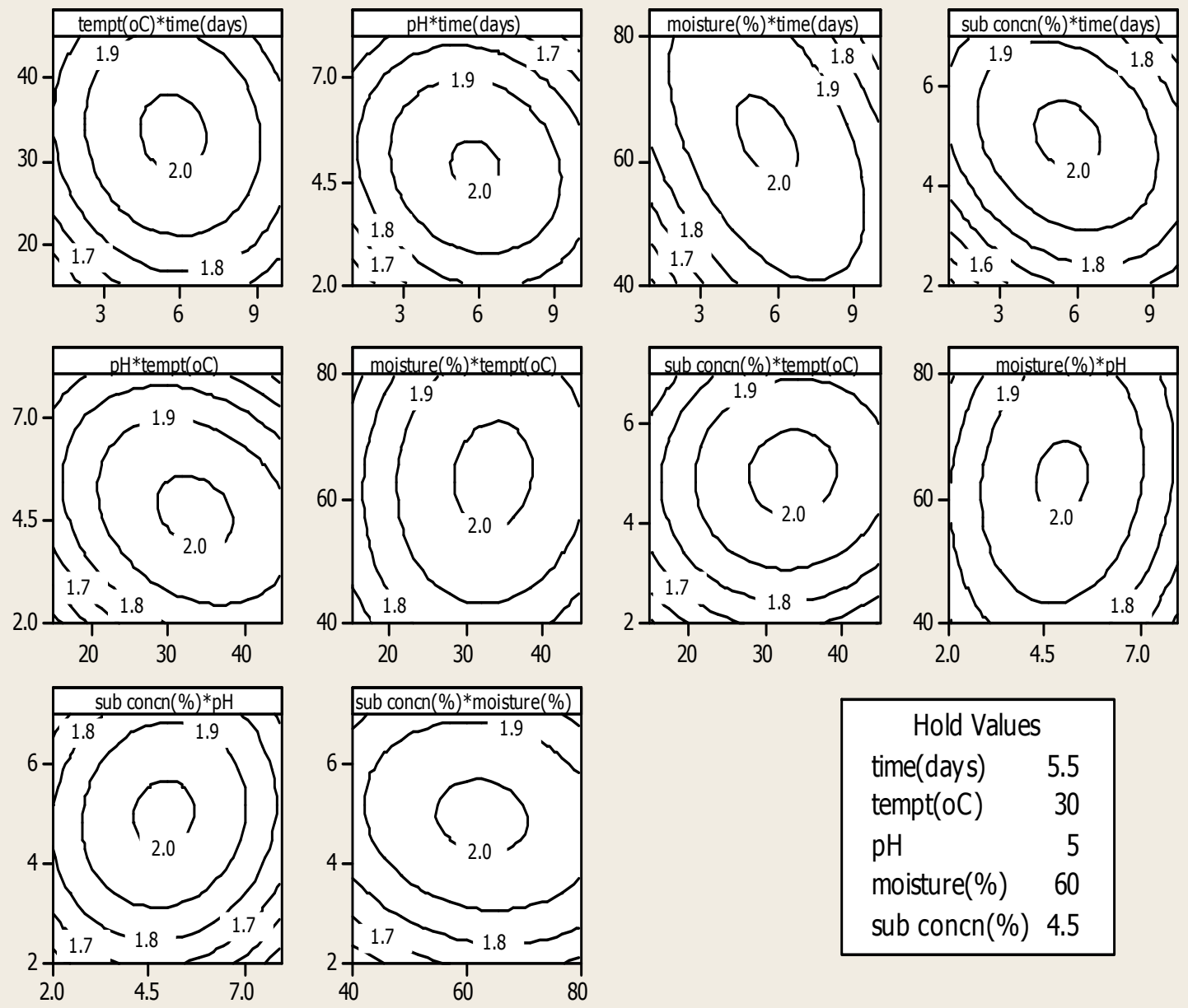

Hold Values time(days) $\quad 5.5$

tempt(oC) $\quad 30$

$\mathrm{pH}$

moisture(\%) 60

sub concn(\%) 4.5

Fig. 1 Contour plot of variables

In each contour plot, two parameters are varied, while the others are unchanged. The plots are obtained from the second order models of Eq. 2. It was obvious that the incubation time, Temperature, 

Lignocellulosic Waste"

$\mathrm{pH}$, Substrate concentration and moisture content exhibited the same tendency on cellulase production. All the ten plots evidently indicated that the response surfaces for cellulase production are showing a clear peak, signifying that optimum settings for maximum cellulase enzyme production are within the boundary.

The optimum operating conditions as predicted by the response optimizer tool of MINITAB 16 were
$2.0303 \mathrm{U} / \mathrm{ml}$ for the parameter values of 5.27 days for incubation time, $34.090 \mathrm{C}$ for temperature, 4.85 for initial $\mathrm{pH}-63.84 \%$ for moisture content and $5.03 \%$ for substrate concentration. The optimization plot obtained is shown in Figure 2. This suggests that the proposed quadratic regression models reasonably optimize the operating conditions.

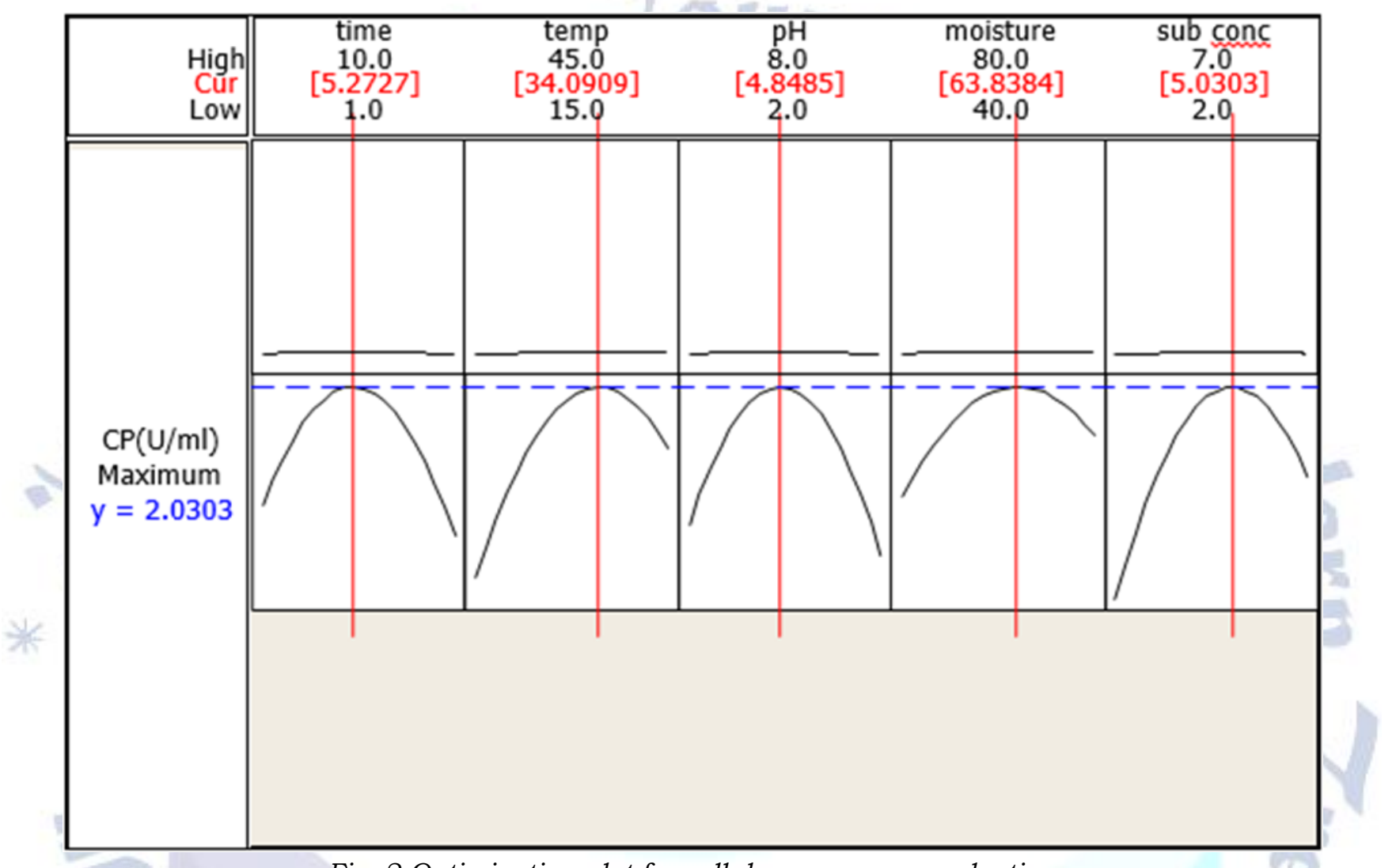

Fig. 2 Optimization plot for cellulase enzyme production

Incubation time is one of the important factors affecting the cellulase enzyme production. It was found that as the incubation time increased, cellulase activity also increased till 5 days and after that there is a decrease in cellulase activity. The optimum incubation time was found to be 5.27 days. "The optimization of the time course is of prime importance for saccharification by fungi" (Khud\& Sing, 1993). The decrease in the cellulase activity after 5 days of incubation period may be because of the reduction of the nutrients or catabolic repression of cellulase enzyme by released glucose.

It was found that when there is an increase in temperature from 15 to $35^{\circ} \mathrm{C}$, cellulase enzyme activity also increased. The optimum temperature was found to be $34.09^{\circ} \mathrm{C}$ at which maximum enzyme activity $(2.03 \mathrm{U} / \mathrm{ml})$ was achieved with mixed culture."As the temperature was further increased, there was a gradual reduction in the cellulase enzyme activity. This may be due to the fact that higher temperature denatures the enzymes mainly cellulase."(SolomonB.O.1999). "Results observed are in line with Mekala et al., (2008) who showed that cellulases production was maximum in flasks when incubated at $33^{\circ} \mathrm{C}$ and decreased with high temperature"

The optimum $\mathrm{pH}$ was found to be 4.85 at which cellulase enzyme activity was maximum and hence optimized for cellulase production from mixed fungal strains. "After that the production of cellulases decreased which might be due to the fact that cellulase are acidic proteins and are greatly affected by the neutral $\mathrm{pH}$ values" (Chandra et al., 2009). 
The moisture content was varied between 40 to $80 \%$. The optimum moisture content was found to be $63.84 \%$.The moisture content has a significant effect on the growth of microorganism "Efficiency of mass transfer in solid- phase particles depends on the moisture and substrate characteristics; however, an excessive increase in moisture content inversely effects the enzyme production. It is because of the fact that more than its optimum amount of water leads to the reduction in the contact surface of the particles" (Dutt\& Kumar 2014)

The cellulase activity increases up to $5 \%$ substrate concentration and then it decreases. "A decrease in enzyme activity beyond maximum (5\%) substrate concentration may be due to inhibitors.

The decrease may also be due to depletion of the nutrients other than the energy source or due to the specific binding of the enzymes with the substrate". (Milala et al ; 2005) conformity of the second-order regression model with the experimental data.

\section{REFERENCES}

[1] Igbinadolor RO 2012, "Fermentation of Cocoa Pod Husk (Theobroma cacao L.) and its Hydrolysate for Ethanol Production using Improved Starter Cultures". PhD Thesis, University of Ibadan, Ibadan, Nigeria

[2] Acharya, P. B., Acharya, D. K. and Modi, H. A. 2008, "Optimization for cellulase production by Aspergillusniger using saw dust as substrate". Afr. J. of Biotechnol. 7 (22): 4147-4152.

[3] Rahna K. Rathnan* and T.Balasaravanan 2014, "Comparative study of saccharification of fruit waste bymono and mixed cultures of cellulolytic fungi" Int.J.Curr.Microbiol.App.Sci(2014) 3(6): 958-970

[4] Fang, H.2010, "Optimization of enzymatic hydrolysis of steam-exploded corn stover by two approaches: Response surface methodology or using cellulase from mixed cultures of Trichodermareesei RUT-C30 and Aspergillusniger NLO2" , Bioresource Technology, 201006

[5] P.A. Soloman, C. Ahmed Basha, M. Velan, N Balasubramanian, P. Marimuthu.2009, "Augmentation of biodegradability of pulp and paper industry waste waterby electrochemical pre-treatment and optimization by RSM" ,Separation and Purification Technology.

[6] A. M. Manilal, P. A. Soloman, C. Ahmed Basha.2020, "Removal of Oil and Grease from Produced Water Using Electro coagulation", Journal of Hazardous, Toxic, and Radioactive Waste

[7] Kuhad, R.C. and A. Singh. 1993, "Enhanced production of cellulases by Penicilliumcitrinum in solid state fermentation of cellulosic residue". World J. Microbiol. Biotechnol., 9,100-101

[8] Solomon, B.O.; Amigun, B.; Betiku, E. Ojumu, T.V., Layokun, S.K. 1999, "Optimization of cellulase production by Aspergillusflavus Linn Isolate NSPR101 Grown on Bagasse". JNSCHE, 16:61-68

[9] Mekala. N.K., R.R. Singhania, R.K. Sukumaran and Pandey. 2008, Cellulose production under solid-state fermentation by Trichodermaressei RUT C30: Statistical optimization of process
ApplBiochemBiotechnol,. $151,122-31$.

[10] Chandra, M., A. Karala, P.K. Sharma and R.S. Sangwan. 2009, "Cellulase production by sixTrichodermaspp.,fermented on medicinal plant processings". J. Ind. Microbiol.Biotechnol, 36,605-609.

[11] Dutt, D., \& Kumar, A. 2014, "Optimization of cellulase production under solid state fermentation by Aspergillusflavus (AT2) and Aspergillusniger (AT3) and its impact on stickies and ink particle size of sorted paper office paper". Cellulose Chemistry and Technology, 48 (3-4), 285- 298.

[12] Milala, M. A., Shugaba, A., Gidado, A., Ene, A.C. \&Wafar, J.A. 2005, "Studies on the Use of Agricultural Wastes for Cellulase Enzyme Production by Aspergillusniger", Research Journal of Agriculture and Biological Sciences. 1 (4),325-328.

[13] Orathai Chavalparit, Maneerat Ongwandee2009., "Optimizing electro coagulation process for the treatment of biodiesel wastewater using response surface methodology”, Journal of Environmental Science. 